\title{
RANGE EXTENDER ICE MULTI-PARAMETRIC MULTI-OBJECTIVE OPTIMIZATION
}

\section{MIKULÁŠ ADÁMEK}

CTU in Prague, Faculty of Mechanical Engineering; Technická 4, Praha 6, 166 07, Czech Republic; E-mail: mikulas.adamek@fs.cvut.cz RASTISLAV TOMAN

CTU in Prague, Faculty of Mechanical Engineering; Technická 4, Praha 6, 166 07, Czech Republic; E-mail: rastislav.toman@fs.cvut.cz

\section{ABSTRACT}

Range Extended Electric Vehicles (REEV) are still one of the suitable concepts for modern sustainable low emission vehicles. REEV is equipped with a small and lightweight unit, comprised usually of an internal combustion engine with an electric generator, and has thus the technical potential to overcome the main limitations of a pure electric vehicle - range anxiety, overall driving range, heating, and air-conditioning demands - using smaller battery: saving money, and raw materials. Even though several REx ICE concepts were designed in past, most of the available studies lack more complex design and optimization approach, not exploiting the advantageous single point operation of these engines. Resulting engine designs are usually rather conservative, not optimized for the best efficiency. This paper presents a multi-parametric and multi-objective optimization approach, that is applied on a REx ICE. Our optimization toolchain combines a parametric GT-Suite ICE simulation model, modeFRONTIER optimization software with various optimization strategies, and a parametric CAD model, that first provides some simulation model inputs, and second also serves for the final designs' feasibility check.

The chosen ICE concept is a 90 degrees V-twin engine, four-stroke, spark-ignition, naturally aspirated, port injected, OHV engine. The optimization goal is to find the thermodynamic optima for three different design scenarios of our concept - three different engine displacements - addressing the compactness requirement of a REx ICE. The optimization results show great fuel efficiency potential by applying our optimization methodology, following the general trends in increasing ICE efficiency, and power for a naturally aspirated concept.

KEYWORDS: RANGE EXTENDER, RANGE EXTENDED ELECTRIC VEHICLE, HYBRID ELECTRIC VEHICLE, BATTERY ELECTRIC VEHICLE, INTERNAL COMBUSTION ENGINE, SPARK-IGNITION, THERMODYNAMIC OPTIMIZATION, GENETIC ALGORITHM

\section{SHRNUTÍ}

Elektrické vozidlo s prodlouženým dojezdem (REEV) je považováno za jednu z možností, jak vyrobit cenově dostupný automobil s nízkými emisemi škodlivin a skleníkových plynů. Hlavní výhoda tohoto konceptu spočivá v malé (lehké) baterii, která by měla svojí kapacitou pokrýt většinu životního cyklu, menší baterie též snižuje cenu vozidla. Aby uživatel nebyl omezen krátkým dojezdem, je pro výjimečné prípady vozidlo vybaveno tzv. prodlužovačem dojezdu. Většinou se jedná o pístový spalovací motor s generátorem, jehož pomocí se nabijí hlavní baterie. Vývojem takového systému se zabývala řada výrobců, většina návrhů se však zakládala pouze na zkušenostech vývojářů a výsledné motory nebyly optimalizovány pro jejich provozní podmínky.

Článek pojednává o návrhu spalovacího motoru pro prodlužovač dojezdu pomocí mnoho-kriteriální a mnoho-cílová optimalizace plně parametrického termodynamického modelu, v kooperaci s CAD modelem. CAD model je použit jako zdroj vstupů pro termodynamický model a současně ke kontrole realizovatelnosti výsledků optimalizace.

Navrhovaný motor je čtyřdobý, atmosférický, dvouválec do V, s rozvodem OHV a nepřimým vstřikem paliva. Celkem jsou optimalizovány tři varianty motoru, lišíí se zdvihovým objemem. Cílem je pokud možno naplnit požadavek na kompaktnost výsledného motoru. Výsledky odpovídají trendům pro zvyšování účinnosti a výkonu spalovacích motorů a vykazují velký potenciál pro snižení spotřeby paliva spalovacího motoru.

\section{KLIĆCVÁ SLOVA: PRODLUŽOVAČ DOJEZDU, ELEKTRICKÉ VOZIDLO S PRODLOUŽENÝM DOJEZDEM. RANGE EXTENDER, ELEKTRICKÝ AUTOMOBIL S PRODLUŽENÝM DOJEZDEM, ELEKTROMOBIL, SPALOVACÍ MOTOR, ZÁŽEHOVÝ MOTOR, TERMODYNAMICKÁ OPTIMALIZACE, GENETICKÝ ALGORITMUS}

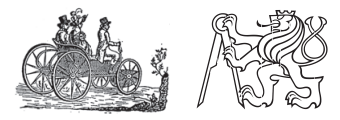




\section{INTRODUCTION}

Range Extended Electric Vehicles (REEV) are one of the doctrines considered for modern low emission vehicles. Main advantage of this concept comes from using the battery as small as possible, this way helping to save the rare and expensive materials used in batteries, still without causing the "range anxiety" to the user. To fully exploit this advantage and to be economically viable, the Range Extender (REX) used in REEV, needs to focus on the price, overall mass, package dimensions, and NVH (Noise Vibration and Harshness). The most common type of range extender (and the only one considered in this paper) is the internal combustion engine (ICE). Several companies have developed a REx ICE to some extent, including OEMs like Lotus, TATA, MAHLE, and some others $[1 ; 2 ; 3 ; 4 ; 5]$.

Design concepts from table 1 suggest, that most of REx ICEs are designed primarily to fulfil the already mentioned requirements. Most of the companies try to keep the price as low as possible, which means sticking to traditional concepts of natural aspiration, indirect injection, and two valves per cylinder heads: the only major difference is AVL with its rotary REx concept [5]. All the evaluated Range Extender engines operate at stoichiometric conditions, allowing for the use of three-way catalyst to fulfill the emission regulation. Although most of the engine concepts were designed from scratch, TATA being the only difference [3], all the designs are mostly based on engineering teams' experience, and internal OEM's empirical tools, and correlations.

Literature indicates that the efficiency is subject to other parameters (especially to price). This way, the entire system's efficiency will always be poor, due to the double tank-to-wheel energy conversion. Nevertheless, the fuel consumption can be significantly reduced (which is always a positive attribute) by the engine optimization for its specific operation, even with "the cheapest" possible setup.

\subsection{DESCRIPTION OF THE GENERAL IDEA}

Our general idea is based on building a detailed fully parametric thermodynamic model of an ICE, equipped with simulation sub-models with appropriate predictive capabilities, and then running a multi-parametric, multi-objective optimization. The optimization result is then checked for its feasibility, using a parametric CAD model of the engine block. This not only provides a necessary engineering feedback, but also helps to capture some important trends, that can occur when changing the basic engine parameters automatically: in our study it is for instance the con-rod elongation when decreasing the bore/ stroke ratio $R_{B / S}$ leading to the crank-train enlargement.

Range Extender engines are designed to provide a specific power output $P_{e}$ (generally enough for the vehicle to achieve the highway speed), usually around $30 \mathrm{~kW}$. The engine is expected to provide this power output at wide-open throttle conditions and for most of its lifetime. This single operating point feature makes the REx engines well suitable for a multi-parametric thermodynamic optimization mentioned above, although the general method can be easily extended on more operating points, and therefore other ICE concepts.

\subsection{GOALS OF THE PAPER}

Our department at Czech Technical University in Prague (CTU) has gathered vast amount of experience on ICE design optimization throughout several former projects [6; 7]. The main goal of this article is to describe an ICE design and optimization method, that combines CAE simulation tools with $C A D$ structural design. The CAD model sets up the simulation input data, and subsequently checks the final design for its feasibility.

\begin{tabular}{|c|c|c|c|c|c|c|c|}
\hline & AVL & MAHLE & TATA & Lotus & KSPG & AVL & \\
\hline Engine configuration & 12 & 12 & 12 & 13 & V2 (90 deg) & Rotary (single) & {$[-]$} \\
\hline Valvetrain layout & $\mathrm{SOHC}$ & $\mathrm{SOHC}$ & $\mathrm{SOHC}$ & $\mathrm{SOHC}$ & $\mathrm{OHV}$ & - & {$[-]$} \\
\hline Valves per cylinder & 2 & 2 & 2 & 2 & 2 & - & {$[-]$} \\
\hline ICE displacement $V_{d}$ & 0.570 & 0.900 & 0.624 & 1.193 & 0.799 & 0.254 & {$[\mathrm{~L}]$} \\
\hline Bore $B$ & 70.0 & 83.0 & 73.5 & 75.0 & 80.0 & - & {$[\mathrm{mm}]$} \\
\hline Stroke $S$ & 74.0 & 83.0 & 73.5 & 90.0 & 79.5 & - & {$[\mathrm{mm}]$} \\
\hline Bore/Stroke ratio $R_{B / S}$ & 0.946 & 1.000 & 1.000 & 0.833 & 1.006 & - & {$[-]$} \\
\hline Compression ratio $r_{c}$ & 11 & 10 & 10.3 & 10 & N/A & & {$[-]$} \\
\hline ICE speed $n_{I C E}$ & 5000 & 4000 & 5500 & 3500 & 4500 & 5000 & [RPM] \\
\hline Mean piston speed $c_{s}$ & 12.333 & 11.065 & N/A & 10.500 & 11.925 & & {$[\mathrm{~m} / \mathrm{s}]$} \\
\hline Brake power $P_{e}$ & 18 & 30 & 28 & 36.8 & 30 & 15 & {$[\mathrm{~kW}]$} \\
\hline BSFC & 250 & 250 & N/A & 241 & N/A & 260 & [g/kWh] \\
\hline
\end{tabular}

TABLE 1: Overview of Range Extender ICE concepts

TABULKA 1: Přehled uspořádání motorů pro Range Extender 
The article is divided into six chapters, that cover all the important aspects of our method, starting with the engine concept selection (in chapter 2); followed by the introduction of the thermodynamic model with its predictive sub-models, and preliminary design analysis in chapter 3. Chapter 4 then discusses the optimization setup, results, and design analyses. Chapter 5 presents some potential future developments of our methodology, and finally, chapter 6 contains important conclusions from our study.

\section{ICE DESIGN CONCEPT}

Choosing the right base concept is extremely important, since it has a strong direct influence on NVH, package, mass, and price. Our concept selection consists of weighing the four criteria (the lower the score, the better) in table 2, for four ICE concepts. Price is the most important parameter (weight of 4), followed by the NVH, mass, and total package: input weighing data for the package, mass, and price were taken directly from a table prepared by Mahle in [8].

The inline two-cylinder engine without balance shaft is a baseline concept; the other assessed two-cylinder designs are the 12 with balance shaft, V-twin engine (V2) with 90 degrees between the cylinder axes, and a two-cylinder with opposed pistons - Boxer engine.

The NVH data in table 2 are our GT-Suite simulation results of each assessed crank-train configuration. We obtained the simulation inputs from parametric CAD model: each engine setup had equal bore, stroke, and conn-rod lengths. First, all variants were first order statically balanced. The 12 engines were simulated for the three feasible ignition orders $(0-360$ degrees, $0-180$ degrees, and $0-450$ degrees), and the best one of these is the 12 baseline in the final table 2 comparisons (thus achieving $100 \%$ ). The $\mathrm{NVH}$ relative value then represents a fraction of imbalanced force between the tested concept and 12 baseline. To enable the averaging of unbalanced forces and unbalanced moments together, the moments are weighted by the estimated bearing spacing. Finally, table 2 suggests, that V2 concept seems to be the most promising for REx ICE, and it is therefore chosen for our subsequent studies.

$\begin{array}{lccccc} & \text { Package } & \text { Mass } & \text { Price } & \text { NVH } & \begin{array}{c}\text { Weighted } \\ \text { average }\end{array} \\ \text { Parameter weight } & 1 & 2 & 4 & 3 & --- \\ \text { I2 without balance shaft } & 100 & 100 & 100 & 100 & 100 \\ \text { I2 with balance shaft } & 100 & 115 & 110 & 31.1 & 86.3 \\ \text { V2 with } 90^{\circ} \text { angle } & 128 & 105 & 102 & 32.7 & 84.4 \\ \text { Boxer } & 104 & 108 & 103 & 44.7 & 86.6\end{array}$

TABLE 2: Decision table for the ICE concept selection TABULKA 2: Rozhodovací tabulka pro výběr konceptu motoru
To sum-up our ICE design concept: later chapters of this article will deal with the optimizations of four stroke, V2, naturally aspirated, spark ignition engine with port fuel injection, and two valves per cylinder (OHV).

\section{THERMODYNAMIC MODEL}

A fully parametric thermodynamic model of our final design concept serves for the subsequent multi-parametric and multi-objective optimizations. The simulation model of the REx ICE was built within the 0D/1D GT-Suite simulation platform, which allows for the simulation of a whole engine thermodynamic cycle. The engine is a virtual one, with a special attention placed on the use of suitable sub-models with predictive abilities. A sub-model without a proper predictive ability could mislead the optimization and guide it to unrealistic results.

\subsection{MAIN ENGINE GEOMETRY}

The main parameters of the thermodynamic model are the cylinder bore $B$, engine operating speed $n_{I C E}$, and bore/stroke ratio $R_{B / S}$.

Valve design parameters are linked to the cylinder bore diameter, using empirical formulas from [9]:

- intake valve diameter $D_{v_{\text {in }}}=0.36 B$; maximum intake valve lift $L_{v_{\text {in }}}=0.3 D_{v_{i n}}$;

- exhaust valve $D_{v_{e x}}=0.3 B$; maximum exhaust valve lift $L_{v_{e x}}=0.3 D_{v_{e x}}$.

The 1D intake and exhaust air paths are also fully parametric, sized accordingly to the cylinder bore $B$, using generic flow coefficients. Intake air path contains also an air filter, throttle, and intake manifold volume. Exhaust path then contains a simplified model of a catalyst brick, to get a realistic exhaust back-pressure.

\subsection{FRICTION SUB-MODEL}

Friction model has a key influence on the resulting ICE's setup, mainly on the $R_{B / S}$ ratio, and ICE operating speed. A simple Chen-Flynn model which was used in previous research studies showed major flaws when used in a multi-parametric optimization due to its lack of predictive ability [7]. Therefore, we applied CTU in-house friction model Vyvaž, created by Macek et al. [10]. In fact, its implementation into GT-Suite thermodynamic model as a sub-assembly.

This friction sub-model has three main parts: pressure part, mechanic part, and friction part. Pressure part consists of series of pipe objects, that simulate engine blow-by, and predict the pressure differences between the piston rings - essential for the piston ring and skirt friction forces calculation. Second - mechanic part, consists of detailed mechanical model of crank-train, and determines all velocities, accelerations, and forces acting on each 
crank-train member. The last - friction part, calculates friction powers, FMEPs, and friction forces for each member of crank-train, and piston assembly (crank bearings, main bearings, piston pin, piston skirt, and piston rings), using results obtained from the respective mechanic and pressure parts. Friction coefficients necessary for finding the friction forces are calculated using a simple model based on a mathematical description of Stribeck curve, that expresses a friction coefficient's dependence on load, speed, and oil viscosity. Vyvaž model also contains empiric relations for oil, and fuel pump losses. Finally, the friction loss in valve train is calculated by Bishop's formula [9].

\subsection{COMBUSTION SUB-MODEL}

Another key area in spark-ignition ICE optimization is the simulation of $\mathrm{SI}$ combustion. We decided to use predictive phenomenological combustion model called EngCylCombSITurb (SITurb) available in GT-Suite. SITurb model calculates a differential equation for entrained mass rate of unburned gas with its main equation 1 , where $\rho_{u}$ are unburned mixture density, and $A_{f}$ a flame area. $S_{L}$ and $S_{T}$ then represent the laminar and turbulent flame speeds.

$\frac{d M_{e}}{d t}=\rho_{u} A_{f}\left(S_{L}+S_{T}\right)$

These two flame speed parameters $-S_{L}$ and $S_{T}$ - limit the flame kernel development: during the initial phases, when the kernel size is still small, the entrainment rate is limited by the laminar flame speed $S_{L}$ (equation 2); equation 3 then accounts for the flame transition into a turbulent one, with $u^{\prime}$ representing the mean fluctuating turbulent velocity, $R_{f}$ the flame radius, and $L_{t}$ the turbulent length scale.

$$
\begin{aligned}
& S_{L}=\left[B_{m}+B_{\phi}\left(\phi-\phi_{m}\right)^{2}\right] \cdot\left(\frac{T_{u}}{T_{0}}\right)^{\alpha} \cdot\left(\frac{p}{p_{0}}\right)^{\beta} \cdot\left(1-2,06 D i l^{0.77 D E M}\right) \\
& S_{T}=C_{s} u^{\prime}\left(1-\frac{1}{1+C_{k}\left(R_{f}{ }^{2} / L_{t}{ }^{2}\right)}\right)
\end{aligned}
$$

SITurb needs a priori information about the turbulent flow in combustion chamber ( $L_{t}$ and $u^{\prime}$ parameters from equation 3 ). The source of these quantities is another GT-Suite's sub-model EngCylFlow (Flow) - a $K-k-\varepsilon$ kinetic energy cascade flow model, that predicts the in-cylinder charge motion and turbulence. More details on both SITurb and Flow models, their evolution, and calibration can be found in $[11 ; 12 ; 13]$.

SITurb uses five different calibration parameters, four from equations 2 and $3\left(D E M, C_{k}, C_{S}\right.$, and $\left.L_{t}\right)$, and Taylor length scale multiplier $C_{\lambda}$ (present in the burnup rate equation $d M_{b} / d t$, as a multiplier for the Taylor microscale of turbulence). Flow then has its own set of four calibration parameters. So, in total we have nine calibration parameters.
First, we performed a thorough sensitivity analysis on these nine total calibration parameters, comparing the combustion model (combination of SITurb and Flow) responses on ICE geometry, ICE operating conditions (load, speed, and cooled EGR content). The sensitivity analysis showed that the burn durations vary in accordance with our general experience: however general burn rates are lower, and the overall sensitivity on operating conditions is higher (load, speed, cooled EGR).

After the sensitivity analysis we performed a calibration of the nine SITurb and Flow calibration parameters using an available set of measurement data with ICE load/speed dependencies. The set of these nine calibrated parameters was then used in all our subsequent REx ICE optimizations, discussed in next chapters.

\subsection{IN-CYLINDER HEAT TRANSFER SUB-MODEL}

Prediction of in-cylinder energy loss due to heat transfer is calculated with a combination of two models.

First, structure and surface temperatures are obtained with a predictive finite element (FE) GT-Suite sub-model EngCylTWallSoln. FE model requires a simplified geometry of all the surfaces, together with coolant and oil boundary conditions. The cylinder structure geometry is also parametric and linked to the engine main geometry.

Second, the heat transfer coefficient is determined using classical Woschni correlation without swirl [14]. This approach was successfully used in some previous CTU research projects on ICE multi-parametric optimization [6; 7].

\subsection{KNOCK SUB-MODEL}

Knock prediction is modeled using a basic GT-Suite model EngCylKnock (Knock), which is based on a standard calculation of knock induction time integral. Knock model obtains the induction time using a Kinetics-Fit-Gasoline correlation. This correlation predicts the induction time with combination of reduced iso-octane oxidation and reduced n-heptane oxidation mechanisms [15].

We did not calibrate the Knock model, because of the time constraints. However, our previous sensitivity studies showed, that the uncalibrated model tends to stay on the safe side in its response to ICE operating condition changes, and this we consider advantageous [16].

\subsection{STRUCTURAL DESIGN ANALYSIS}

There are two main reasons for the use of a parametric CAD model of our V2 engine block:

- CAD model helps us prepare some of the simulation input data for the friction model Vyvaž, that requires detailed knowledge of crank-train masses, and con-rod compensating moment of inertia with its coordinates.

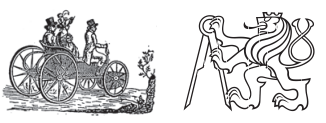


- Subsequently, it serves for the final structural design's feasibility check - after running the multi-parametric optimizations.

There are some relations, that can be established only with this parametric CAD model, and which are important inputs for Vyvaž friction model - as we have already discussed. First of those relations is the relation between the piston assembly's mass and cylinder bore; the second one is the relation between the con-rod's length $l$ and its geometry parameters; third one is the relation of con-rod ratio $\lambda$ with bore/stroke ratio $R_{B / S \text {, }}$ and bore diameter $B$ in equation 4 ( $n$ and $c$ are functions of cylinder bore; $\lambda=S /\left(2^{\star} l\right)$. One can assume, that a designer would try to minimize the package volume using a con-rod as short as possible, because this is a parameter that plays a major role in determining the crank-train's size, and therefore the total engine's package volume.

$\lambda=\left(-\sqrt{\frac{\left(R_{B / S}-0.75\right)^{2}}{0.05882^{2}}+1}\right) \cdot 0.0125+n+\left(R_{B / S} c-0.75 c\right)$

Figure 1 shows this relation in comparison with data acquired directly from the CAD model (marked by "REL" suffix in legend), for four different bore diameters $B$. Our correlation gives feasible results, and these are fed into Vyvaž sub-model ensuring higher optimization accuracy and results' feasibility.

Figure 2 with con-rod ratio $\lambda$ dependence on $R_{B / S}$ ratio then shows, that for $R_{B / S}$ ratios under 0.5 , the con-rod length grows rapidly (lower $\lambda$ ratio means longer con-rod length). This Figure also clarifies how we chose the $R_{B / S}$ ratio lower/upper limits in table 3 , that will be introduced in next chapter.

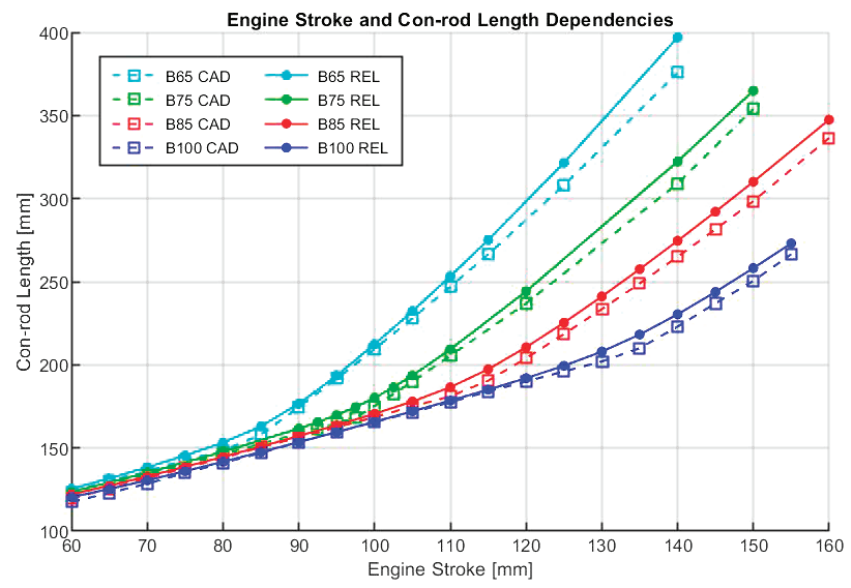

FIGURE 1: Con-rod length dependence on engine stroke (values obtained with relation 4 are marked with "REL")

OBRÁZEK 1: Délka ojnice v závislosti na zdvihu motoru („REL” značí hodnoty získané pomocí vztahu 4)

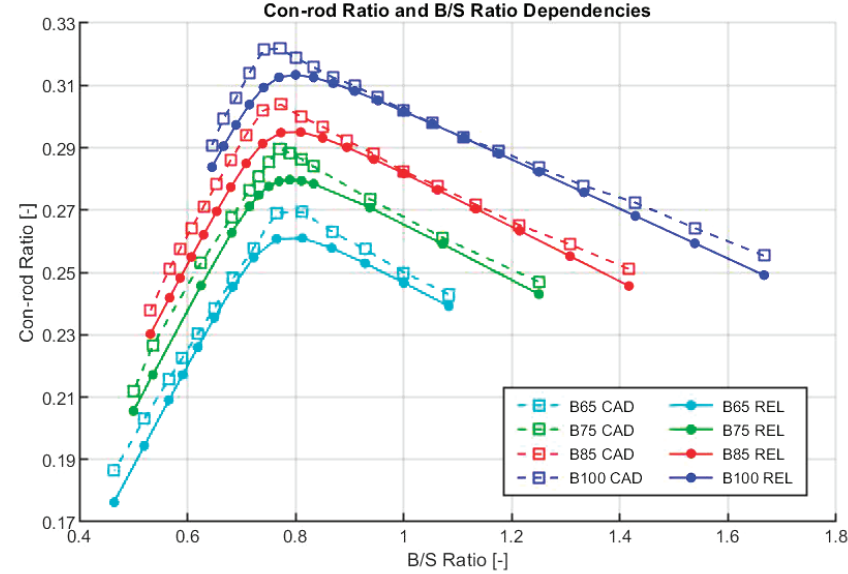

FIGURE 2: Con-rod ratio dependence on bore/stroke ratio $R_{B / S}$ OBRÁZEK 2: Závislost ojničního poměru na poměru zdvihu a vrtání $R_{B / S}$

\section{OPTIMIZATION SCENARIOS}

A general expectation in an optimization aimed for the best efficiency natural aspirated ICE is, that it will lead to relatively large displacement. This is however in a strong disagreement with the basic REx requirement for a compact design package, and low overall mass. To test this expectation, we decided to optimize our REx ICE model in three different scenarios, with the same $P_{e}$ target of $30 \mathrm{~kW}$, at the best possible BSFC. The only difference between the scenarios is the engine displacement. In the first scenario, called $V_{\max }$, the optimizer is not limited by the cylinder displacement, only by the minimum/maximum cylinder bore diameter $B$ and bore/stroke ratio $R_{B / S}$. Main point of this scenario is to test, whether the optimization will properly follow the expected trends in increasing the ICE efficiency.

Second scenario $\mathrm{V}_{05}$ concept uses a fixed cylinder displacement of $0.5 \mathrm{~L}$, hence the name. This engine's total displacement is slightly larger than most REx ICEs analyzed in chapter 1, but it is probably the most common engine displacement in automotive industry.

Last scenario is $\mathrm{V}_{035}$, should represent the design's compactness requirement. Since total displacement of $0.7 \mathrm{~L}$ is rather small for $30 \mathrm{~kW}$ power output, we expect the optimized design to turn out as "sporty".

\subsection{OPTIMIZATION SETUP}

There are nine total parameters chosen for the optimizations, summed-up in table 3 ( $S A$ is the spark advance angle; the firing TDC represents the 0 deg CA in all angular parameters). The $\mathrm{V}_{\max }$ scenario optimizes all of them; in the case $\mathrm{V}_{05}$ and $\mathrm{V}_{035}$ scenarios bore and stroke values are linked together because of the "locked volume", and the optimizer varies only the $R_{B / S}$ ratio. 


\begin{tabular}{|c|c|c|c|c|c|c|c|c|c|}
\hline Parameter & $\begin{array}{c}B \\
{[\mathrm{~mm}]}\end{array}$ & $\begin{array}{c}R_{B / S} \\
{[-]}\end{array}$ & $\begin{array}{l}r_{c} \\
{[-]}\end{array}$ & $\begin{array}{c}n_{I C E} \\
{[\mathrm{RPM}]}\end{array}$ & $\begin{array}{c}S A \\
{[\operatorname{deg} C A]}\end{array}$ & $\begin{array}{c}I V O \\
{[\operatorname{deg} C A]}\end{array}$ & $\begin{array}{c}E V C \\
{[\operatorname{deg} C A]}\end{array}$ & $\begin{array}{c}F_{I V C} \\
{[-]}\end{array}$ & $\begin{array}{c}F_{E V O} \\
{[-]}\end{array}$ \\
\hline Lower limit & 60 & 0.5 & 6 & 1000 & 80 & 290 & 320 & 0.7 & 0.7 \\
\hline Upper limit & 100 & 1.5 & 15 & 7000 & -10 & 380 & 450 & 1.3 & 1.3 \\
\hline Resolution & 0.1 & 0.005 & 0.1 & 50 & 1 & 1 & 1 & 0.004 & 0.004 \\
\hline
\end{tabular}

TABLE 3: Limits and resolutions of the optimization parameters

TABULKA 3: Rozsahy a rozlišení optimalizovaných parametrů

Parameters $F_{I V C}$ and $F_{E V O}$ multiply the width of the base valve lift curves, and by that control the inlet valve opening event or exhaust valve closing events respectively (Note: unity values of $F_{I V C}$ and $F_{E V O}$ correspond to 210 deg CA from open to closed valve, at $1 \mathrm{~mm}$ lift).

All the optimizations are run using modeFRONTIER's pilOPT hybrid algorithm, that combines local and global search, and is recommended for multi-objective problems [17]. pilOPT algorithm is then searching for the thermodynamic optima, trying to fulfill also the $P_{e}$ demand. Each scenario optimization took about 10000 design iterations.

As we have already discussed in our introductory part, we use a fully parametric CAD model of V2 engine block for the design feasibility check, since a thermodynamically optimal design is not necessarily also feasible from the structural design viewpoint.

\subsection{OPTIMIZATION RESULTS}

Since the optimization is multi-objective, optimal results are received in a Pareto front, which is a set of optimal values, where achieving improvement in one of the objectives will worsen the other. In our case, designs with lower BSFC tend to be further away from the desired power output, and vice versa. The optimal designs were then selected from the Pareto front using standard criterial function $F$ (equation 5), where the weight coefficient for $\operatorname{BSFC}\left(\alpha_{i 1}\right)$ is 0.9 , and for brake power $P_{e}\left(\alpha_{i 2}\right)$ it is 0.1 . The fraction $X_{i} / X_{i, \text { max }}$ in equation 5 represents a normalization of Pareto front values, so that the two different objective functions $X_{i}$ can be combined into one equation; $X_{i, \max }$ is the maximum value of the $\mathrm{i}^{\text {th }}$ objective function in Pareto set.

$F=\sum_{i=1}^{k} \alpha_{i} \frac{X_{i}}{X_{i, \max }}$

\subsubsection{OVERALL RESULTS}

Results of all three optimization scenarios are summarized in table 4 and Figure 3. While table 4 contains the set of optimal (independent - labelled with ' ${ }^{* \prime}$ ) parameters, main thermodynamic outputs, and some dependent parameters; Figure 3 then shows the comparison of valve lift curves for each scenario.

$\begin{array}{lcccc} & \mathrm{V}_{\max } & \mathrm{V}_{05} & \mathrm{~V}_{035} & \\ B^{*} & 99.50 & 98.15 & 75.74 & {[\mathrm{~mm}]} \\ R_{B / S}{ }^{*} & 0.735 & 1.485 & 0.975 & {[-]} \\ n_{I C E}{ }^{*} & 2150 & 3200 & 4650 & {[\mathrm{RPM}]} \\ r_{c}{ }^{*} & 14.2 & 12.7 & 14.1 & {[-]} \\ S A^{*} & 22.0 & 36.0 & 27.0 & {[\mathrm{deg} \mathrm{CA}]} \\ S^{*} & 135.37 & 66.09 & 77.68 & {[\mathrm{~mm}]} \\ V_{d} & 2.11 & 1.00 & 0.70 & {[\mathrm{~L}]} \\ C_{S} & 9.70 & 7.05 & 12.04 & {[\mathrm{~m} / \mathrm{s}]} \\ \text { BSFC } & 214.0 & 229.8 & 238.5 & {[\mathrm{~g} / \mathrm{kWh}]} \\ \text { BMEP } & 7.95 & 11.25 & 11.07 & {[\mathrm{bar}]} \\ \eta_{v} & 58.67 & 89.27 & 91.08 & {[\%]} \\ \eta_{m} & 92.78 & 90.70 & 84.48 & {[\%]}\end{array}$

TABLE 4: Results for all three optimization scenarios

TABULKA 4: Výslední hodnoty pro všechny optimalizační scénáře

The $V_{\max }$ scenario engine turned out as the most efficient, with the best BSFC value of $214 \mathrm{~g} / \mathrm{kWh}$. But it is also the largest of the three engines. The final $V_{\max }$ volume is $2.1 \mathrm{~L}$, with a long stroke $R_{B / S}$ of 0.735 , leading to a mean piston speed of $9.70 \mathrm{~m} / \mathrm{s}$. Large volume means that the engine was able to achieve demanded $P_{e}$ with only 2150 RPM - following the ICE down-speeding trend. A look at the Figure 3 shows, that the $V_{\max }$ engine uses inlet valve open for extremely short time, running in Miller cycle. Tendency to push towards Miller cycle is well known. However, in comparison to similar previous optimizations [7], the optimizer was given bigger freedom in valve timing parameters, resulting in "stronger" Miller cycle. The combination of large volume, low speed, and Miller cycle leads to rather small BMEP of 7.95 bar, and volumetric efficiency of only $58.7 \%$. Although such REX engine would hardly fulfil package requirement, lower BMEP engines tend to be robust and reliable, which might be useful for an ICE operating at WOT right after start-up.

$\mathrm{V}_{\max }$ concept also has relatively large compression ratio of 14.2. This can seem extreme, but in combination with spark advance of 22 deg CA BTDC, and Miller cycle especially, it is feasible.

The $V_{05}$ scenario achieves worse BSFC results compared to the $\mathrm{V}_{\max }$ variant, with a short stroke $R_{B / S}$ ratio of 1.485 , at higher operating speed $3200 \mathrm{RPM}$, but lower $c_{s}$ of $7.05 \mathrm{~m} / \mathrm{s}$. We have 


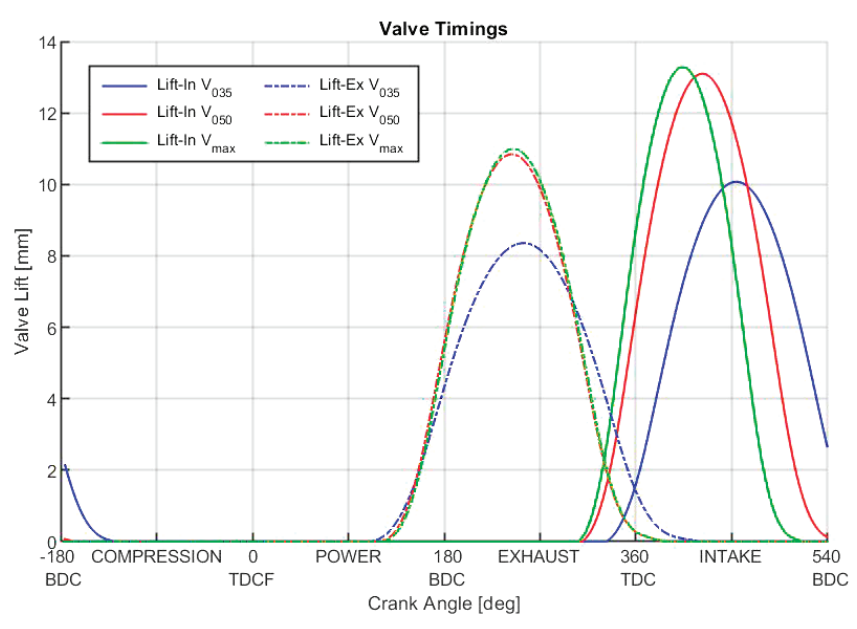

FIGURE 3: Valve lift curves of optimized engines

OBRÁZEK 3: Ventilové zdvihové křivky optimalizovaných motorů

seen some similar behavior before e.g. in [7], but there it was caused probably by the simple Chen-Flynn friction model [9], that lacks the predictive abilities, and therefore preferred this short-stroke configuration. In this case, however, we think it is because of achieving good volumetric efficiency, due to the direct link between the bore size and inlet valves diameter. The fact that $V_{05}$ engine achieves high BMEP of 11.25 bar despite using some level of Millerization supports our assumption. Compression ratio is 12.7 which is lower than in the previous $\mathrm{V}_{\max }$ scenario, due to the short stroke configuration, that leads to the increased knock tendencies [1]. However, with such a short stroke, even this compression ratio might be technically challenging to achieve.

The last $\mathrm{V}_{035}$ scenario was chosen with rather small volume for such power output; the engine BSFC, ICE operating speed, and mean piston speed grow accordingly. The optimal $R_{B / S}$ ratio is also a bit surprising, since the engine is slightly long stroke. The reason for this is probably the tendency of Vyvaž friction model (according to its author) to overrate the piston skirt friction growing with engine bore. Another parallel explanation is that Bishop's formula uses the ICE operating speed and valve diameter to determine the valvetrain losses: since the valve diameter is linked directly to the engine bore, smaller bore actually leads to relatively high mechanical efficiency of $84.5 \%$, despite high RPMs and mean piston speed (4650 RPM, $12.04 \mathrm{~m} / \mathrm{s}$ ). Yet, the small inlet valve area, pushes the optimizer to change the valve timing approach, compared to the first two scenarios: $\mathrm{V}_{035}$ engine uses a later IVC angle compared to other scenarios. This way the engine achieves sufficient cylinder filling, although with slight backflow just before IVC, reducing effective compression ratio thus improving knock robustness.

\subsubsection{PACKAGE COMPARISON}

From the package standpoint, all three design scenarios were also compared using parametric CAD model of $\mathrm{V} 2$ engine block, since comparing just their volume is not particularly accurate, because the engine size is strongly influenced by $R_{B / S}$ ratio, and con-rod length (Figure 4, and table 5). Table 5 also contains estimated masses of the main engine components.

The $V_{\max }$ engine is by far the largest of the three - as expected. It is rather interesting, that the two other scenarios $V_{05}$ and $\mathrm{V}_{035}$ are very similar from the package standpoint, though $\mathrm{V}_{035}$ is slightly shorter. According to our CAD model, all designs are

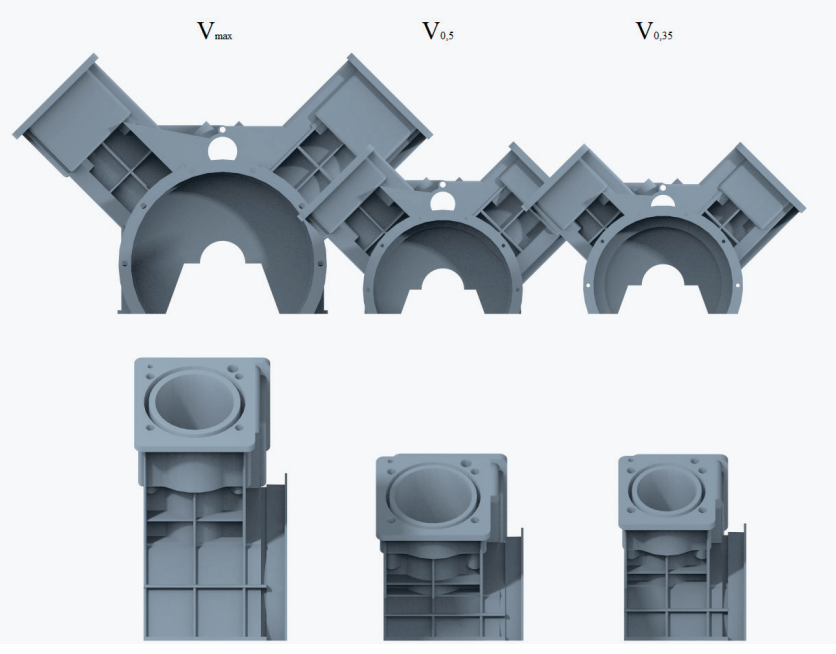

FIGURE 4: Engine block CAD models (from left $\mathrm{V}_{\max }, \mathrm{V}_{05}, \mathrm{~V}_{035}$ ) OBRÁZEK 4: CAD modely bloků (zleva $\mathrm{V}_{\text {max }}, \mathrm{V}_{05}, \mathrm{~V}_{035}$ )

\begin{tabular}{|c|c|c|c|c|c|c|c|}
\hline & $\begin{array}{l}\text { Width } \\
{[\mathrm{mm}]}\end{array}$ & $\begin{array}{c}\text { Height } \\
{[\mathrm{mm}]}\end{array}$ & $\begin{array}{l}\text { Length } \\
{[\mathrm{mm}]}\end{array}$ & $\begin{array}{c}\text { Block } \\
\text { Mass } \\
{[\mathrm{kg}]}\end{array}$ & $\begin{array}{c}\text { Piston assembly } \\
\text { Mass } \\
{[\mathrm{kg}]}\end{array}$ & $\begin{array}{c}\text { Con-rod } \\
\text { Mass } \\
{[\mathrm{kg}]}\end{array}$ & $\begin{array}{c}\text { Con-rod } \\
\text { Length } \\
{[\mathrm{mm}]}\end{array}$ \\
\hline $\mathrm{V}_{\max }$ & 574.8 & 356.1 & 192.3 & 13,15 & 0,73 & 0,70 & 219,9 \\
\hline $\mathrm{V}_{05}$ & 401.2 & 231.8 & 186.6 & 6,58 & 0,71 & 0,54 & 126,7 \\
\hline $\mathrm{V}_{035}$ & 389.4 & 232.5 & 160.9 & 5,88 & 0,36 & 0,57 & 144,5 \\
\hline
\end{tabular}

TABLE 5: Engine blocks' dimensions and estimated components' masses

TABULKA 5: Rozměry bloků motorů a odhadnuté hmotnosti hlavních komponent

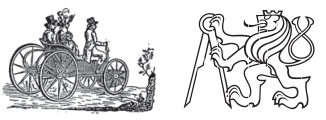


feasible; however, $\mathrm{V}_{05}$ variant is on the limit, and some of the design features would be a very tight fit.

\section{POTENTIAL FOR FUTURE DEVELOPMENT OF THE OPTIMIZATION METHODOLOGY}

The designs resulting from our optimizations are generally feasible and achieve high yet not unrealistic efficiencies for OHV designs. Despite these positive results, there is still some further potential in the development of our optimization methodology, especially from the viewpoint of the structural design, specifically in two areas.

The first area is referenced to the fact, that we do not scale the main and conn-rod bearing diameters with bore size. And these are important inputs for Vyvaž friction model. A change in the con-rod bearing diameter would also influence the relation developed for con-rod ratio calculation (equation 4). We have already prepared some possible corrections to this formula, but these will be applied together with the bearing size scaling.

The second area is connected to the valve lift scaling. Currently we use a scaling coefficient $F_{v}$ for the respective intake/exhaust lift vectors (equation 6 , where $L_{v}$ is the valve lift and $D_{v}$ the valve diameter) based on Heywood's formula, first introduced in chapter 3.1 on main engine geometry.

$0.3 \leq \frac{L_{v}}{D_{v}}=>F_{v}=0.3 \frac{D_{v}}{L_{v}}$

This simple relation gives decent result from the thermodynamic perspective. Further increase in the intake valve lift from the optimal value of the $\mathrm{V}_{\max }$ design has a small additional positive effect on BSFC, which is clear from Figure 5.

In practice, the lift curve is usually limited by the valve train dynamics. Valve acceleration is determined by the lift curve

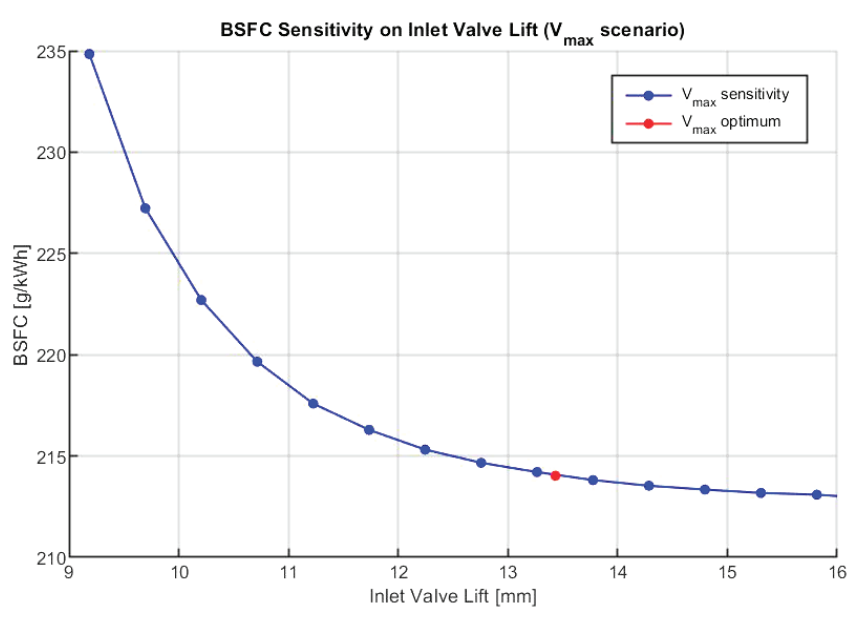

FIGURE 5: BSFC dependence on the inlet valve lift for $\mathrm{V}_{\max }$ scenario OBRÁZEK 5: Závislost měrné spotřeby na zdvihu sacího ventilu pro scénář $\mathrm{V}_{\max }$ shape - this acceleration relation can be simplified to just valve lift and engine speed. However, REx ICE operates only in one primary operating point and it is not controlled by the driver: this means, that there is little chance of over-speeding the engine. The lift curves can be therefore designed exactly for this one operating point, even possibly saving some extra fuel.

\section{CONCLUSION}

Our paper presents a multi-parametric, multi-objective design optimization methodology, that was tested on a case of three design scenarios for a four-stroke, V-twin, natural aspirated, spark-ignition REx ICE, operating in a single point REEV's operation.

We defined our REx engine concept, aiming at the best possible balance of achievable mass, package, overall design simplicity and therefore low cost, based on the literature research and using a design selection table. The other layouts that we considered were inline two-cylinder variants with or without balance shaft, and an opposed pistons engine - Boxer.

Thermodynamic 0D/1D model was built within the GT-Suite simulation environment, with a special emphasis on predictive ability of its sub-models. Our paper briefly discusses some of these sub-models: CTU in Prague in-house built friction model, GT-Suite's phenomenological predictive SI combustion model, knock model, and finally the in-cylinder heat transfer model. Apart from the GT-Suite simulation model, our methodology uses also a parametric CAD model of the engine block. This CAD model provides some important input data for the GT-Suite sub-models to enhance the optimization accuracy, and it is also used for the optimization result structural design's feasibility check. Finally, the multi-parametric and multi-objective optimizations of three different design scenarios featuring different engine displacement with the same power output goal were carried out in a modeFRONTIER optimization platform, using a hybrid algorithm pilOPT. Resulting REx ICE designs are realistic, following the current trends of ICE efficiency increase (Millerization and down-speeding) and power increase for natural aspirated engine.

Our future work will mainly focus on further enhancements of our optimization methodology, adding more details of the crank-train mechanism design into the simulation sub-models. Future simulation studies will consider different engine layouts.

\section{ACKNOWLEDGEMENTS}

This work was realized using support of:

- Technological Agency, Czech Republic, programme National Competence Centres, project \# TN01000026 Josef Bozek National Center of Competence for Surface Vehicles. 
- The Grant Agency of the Czech Technical University in Prague, grant No. SGS19/104/OHK2/2T/12.

This support is gratefully acknowledged.

\section{LIST OF ABBREVIATIONS}

$\begin{array}{ll}\text { BTDC } & \text { Bottom Top Dead Center } \\ \text { CAD } & \text { Computer Aided Design } \\ \text { CAE } & \text { Computer Aided Engineering } \\ \text { CTU } & \text { Czech Technical University in Prague } \\ \text { EGR } & \text { Exhaust Gas Recirculation } \\ \text { FE } & \text { Finite Element } \\ \text { I2 } & \text { Inline two-cylinder Engine } \\ \text { I3 } & \text { Inline three-cylinder Engine } \\ \text { ICE } & \text { Internal Combustion Engine } \\ \text { NVH } & \text { Noise Vibration and Harshness } \\ \text { OEM } & \text { Original Equipment Manufacturer } \\ \text { OHV } & \text { Over Head Valve } \\ \text { REEV Range } & \text { Extended Electric Vehicle } \\ \text { REx } & \text { Range Extender } \\ \text { SI } & \text { Spark Ignition } \\ \text { SOHC } & \text { Single Over Head Camshaft } \\ \text { TDC } & \text { Top Dead Center } \\ \text { V2 } & \text { V-twin Engine } \\ \text { WOT } & \text { Wide Open Throttle } \\ \text { FMEP } & \text { Friction mean effective pressure } \\ \text { BMEP } & \text { Brake mean effective pressure } \\ \text { BSFC } & \text { Brake-specific fuel consumption } \\ \text { CA } & \text { Crank angle } \\ \end{array}$

\section{LIST OF SYMBOLS}

$\begin{array}{ll}A_{f} & \text { Flame area } \\ B_{m} & \text { Maximum laminar speed } \\ B \phi & \text { Laminar speed roll-of value } \\ C_{K} & \text { Flame kernel growth multiplier } \\ C_{S} & \text { Turbulent flame speed multiplier } \\ C_{\lambda} & \text { Taylor length scale multiplier } \\ D_{v_{e x}} & \text { Exhaust valve diameter } \\ D_{v_{\text {in }}} & \text { Intake valve diameter } \\ F_{v} & \text { Valve lift scaling coefficient } \\ L_{v_{e x}} & \text { Maximum exhaust valve lift } \\ L_{v_{i n}} & \text { Maximum intake valve lift } \\ L_{t} & \text { Turbulent length scale } \\ M_{b} & \text { Burnup mass } \\ M_{e} & \text { Entrained mass } \\ P_{e} & \text { ICE brake power } \\ R_{B / S} & \text { Bore/stroke ratio } \\ R_{f} & \text { Flame radius } \\ S_{L} & \text { Laminar flame speed } \\ S_{T} & \text { Turbulent flame speeds }\end{array}$

\begin{tabular}{ll}
$V_{d}$ & ICE displacement \\
$X_{k, \text { max }}$ & Pareto set's maximum value of the objective \\
& function \\
$X_{k}$ & Optimization objective function \\
$C_{s}$ & Mean piston speed \\
$n_{I C E}$ & Engine speed \\
$p_{0}$ & Reference pressure \\
$r_{c}$ & Compression ratio \\
$\alpha_{k}$ & Criterial function weight coefficient \\
$\eta_{m}$ & Mechanical efficiency \\
$\eta_{v}$ & Volumetric efficiency \\
$\rho_{u}$ & Density of unburned gas \\
$\phi_{m}$ & Fuel/air equivalence ratio at maximum laminar \\
& flame speed \\
$B$ & Bore \\
$D E M$ & Dilution exponent multiplier \\
$D i l$ & Mass fraction of the residuals in the unburned zone \\
$F$ & Criterial function \\
$S$ & Stroke \\
$S A$ & Spark advance angle \\
$c$ & Con-rod ratio relation coefficient 1 \\
$n$ & Con-rod ratio relation coefficient 2 \\
$p$ & Pressure \\
$u^{\prime}$ & Mean fluctuating turbulent velocity \\
$\beta$ & Pressure exponent \\
$\phi$ & Con-rod ratio \\
& Fuel/air equivalence ratio \\
& \\
\hline &
\end{tabular}

\section{REFERENCES}

[1] Turner J, Blake D, Moore J, et al. (2010) The Lotus Range Extender Engine. SAE International 2010-01-2208:34. https://doi.org/10.4271/2010-01-2208

[2] Andert J, Kohler E, Niehues J, Schurmann G (2012) KSPG RANGE EXTENDER: A NEW PATHFINDER TO ELECTROMOBILITY. MTZ WORLDWIDE 2012:7. https://doi.org/10.1007/s38313-012-0170-1

[3] Agarwal A, Lewis A, Akehurst S, et al. Development of a Low Cost Production Automotive Engine for Range Extender Application for Electric Vehicles. SAE International 2016-01-1055. https://doi.org/10.4271/2016-01-1055

[4] Atzwanger M, Hubmann C, Schoeffmann W, et al. Two-Cylinder Gasoline Engine Concept for Highly Integrated Range Extender and Hybrid Powertrain Applications. SAE International 2010-09-28. https://doi.org/10.4271/2010-32-0130

[5] Fraidl GK, Fisher R, Hubmann C, et al. (2009) Range Extender Module: Enabler for Electric Mobility. ATZautotechnology 2009:40-49. https://doi.org/10.1007/BF03247140 
[6] Bogomolov S, Dolecek V, Macek J, et al. (2014) Combining Thermodynamics and Design Optimization for Finding ICE Downsizing Limits: 2014-04-01. SAE International 2014. https://doi.org/10.4271/2014-01-1098

[7] Toman R, Brankov I (2018) Multi-Parametric and MultiObjective Thermodynamic Optimization of a SparkIgnition Range Extender Ice. Sciendo 2018:459-466. https://doi.org/0.5604/01.3001.0012.4368

[8] Bassett M, Thatcher I, Bisordi A, et al. Design of a Dedicated Range Extender Engine. SAE International 2011-01-0862. https://doi.org/10.4271/2011-01-0862

[9] HEYWOOD, John. Internal combustion engine fundamentals. 1. New York: McGraw-Hill, 1988. ISBN 978-0070286375.

[10] Macek J, Fuente D, Emrich M (2011) A Simple Physical Model of ICE Mechanical Losses. SAE International 2011-01-0610. https://doi.org/10.4271/2011-01-0610

[11] Mirzaeian M, Millo F, Rolando L (2016) Assessment of the Predictive Capabilities of a Combustion Model for a Modern Downsized Turbocharged SI Engine. SAE International 2016-01-0557. https://doi.org/10.4271/2016-01-0557

[12] Rastislav T, Jan M (2017) Evaluation of the Predictive Capabilities of a Phenomenological Combustion Model for Natural Gas SI Engine. Journal of Middle European Construction and Design of Cars: The Journal of Czech Technical University 2017:37-48. https://doi.org/10.1515/MECDC20170007

[13] Fogla N, Bybee M, Mirzaeian M, et al. (2017) Development of a K-k- $\varepsilon$ Phenomenological Model to Predict In-Cylinder Turbulence. SAE International Journal of Engines 10:562 - 575. https://doi.org/10.4271/2017-01-0542

[14] Woschni G (1967) A Universally Applicable Equation for the Instantaneous Heat Transfer Coefficient in the Internal Combustion Engine. SAE International 670931. https://doi.org/10.4271/670931

[15] Ra Y, Reitz R (2008) A reduced chemical kinetic model for IC engine combustion simulations with primary reference fuels. ScienceDirect 2008:713-738. https://doi.org/10.1016/j.combustflame.2008.05.002

[16] Adámek M (2020) OPTIMALIZACE TERMODYNAMIKY A KONSTRUKCE SPALOVACÍHO MOTORU PRO RANGE EXTENDER. Diplomová práce

[17] ModeFrontier User Guide: Release 2018R3, 2018 ed.. ESTECO 